\title{
Predicting Student Satisfaction with an Emphasis on Campus Recreational Sports and Cultural Facilities in a Turkish University
}

\author{
Ali Kemal Çelik ${ }^{1} \&$ Kübra Akyol ${ }^{2}$ \\ ${ }^{1}$ Department of Quantitative Methods, Atatürk University, Erzurum, Turkey \\ ${ }^{2}$ Department of Econometrics, Atatürk University, Erzurum, Turkey \\ Correspondence: Ali Kemal Çelik, Faculty of Economics and Administrative Sciences, Department of \\ Quantitative Methods, Atatürk University, Erzurum 25240, Turkey. Tel: 90-442-231-2122. E-mail: \\ akemal.celik@atauni.edu.tr
}

Received: September 30, 2014 Accepted: December 12, 2014 Online Published: March 26, 2015

doi:10.5539/ies.v8n4p7

URL: http://dx.doi.org/10.5539/ies.v8n4p7

\begin{abstract}
The main purpose of this paper was to determine the predictors of student satisfaction focusing on campus recreational sports and cultural facilities. The present study utilized data from a written-questionnaire administered to one thousand adult undergraduate students. The dependent variable used in predicting student satisfaction was satisfaction levels of the respondents. Due to the ordinal nature of the dependent variable, an ordered logit model was performed to determine demographic and socio-economic determinants of campus sports and cultural facility satisfaction. Ordered logit estimation results revealed that younger aged, higher income, tuition loan holder, classical or folk music listener students studying in social sciences were less likely to have higher satisfaction than their counterparts. In addition, for many selected services, most of the students declared their dissatisfaction. Although there is an increasing number of studies conducted on student satisfaction in the existing literature, studies focusing on campus sports and cultural facility satisfaction are limited. This study is probably the first attempt to examine the predictors of campus sports and cultural facility satisfaction in northeastern Turkey using one of the categorical data estimation method.
\end{abstract}

Keywords: student, satisfaction, recreation, sports, cultural, facility, ordered logit model, Turkey

\section{Introduction}

Higher education is widely considered as a part of service industry since the orientation of its institutions is to provide quality services to students in an increasing competitive environment (Yeo, 2008). In this respect, meeting students' needs and expectations come into prominence to attract and retain quality students (Elliott \& Shin, 2002). The evaluation of the student experience can be divided into two approaches. The first approach involves methods with an emphasis on evaluating teaching and learning, while the second approach deals with methods that evaluate the total student experience (Aldridge \& Rowley, 1998). When students are considered as consumers of higher education, their level of satisfaction plays a relatively important role for institutional success in terms of effectiveness and recruitment (Thomas \& Galambos, 2004). Student satisfaction is adopted as a short-term attitude resulting from an evaluation of student's educational experience and student life is a web of interconnected experiences that affects student satisfaction (Elliott \& Healy, 2001). A satisfied student population is considered as a source of competitive advantage with several advantageous outcomes involving student retention and loyalty (Arambewela \& Hall, 2009). Every higher education institution has an important process such that the retention of students within the university campus until the end of their career which is closely related to the satisfaction with service experience (Melchor-Cardona \& Bravo, 2012).

Student satisfaction with their educational experience is the result of a complex set of factors and better understanding of these factors with a combination to influence satisfaction is relatively important for many higher education institutions (Appleton-Knapp \& Krentler, 2006). One of the main goals of student satisfaction surveys is to identify factors of relevance to the student satisfaction concept as well as their relative importance in which these surveys appear to be a potential competitor to more traditional student assessment schemes of teaching and learning (Wiers-Jenssen et al., 2002). Student satisfaction can be examined either concentrating on the improvement of students' least-satisfied experience or identifying aspects of an experience that most differentiate students' general satisfaction (Thomas \& Galambos, 2004). As student experience concept tends to 
be influenced by different factors, a successful evaluation of student experience varies from one institution to another (Benckendorff et al., 2009). In theory, characteristics of institutional environment such as the physical, academic, social and psychological variables provide to determine student enrollment and retention. To this end, facility management is the main indicator of student-institution fit (Price et al., 2003).

Leisure is generally considered as a complex human need which can be fulfilled by the production and consumption of individual pleasant experiences. In this sense, the boundaries of leisure on the basis of different tastes can be defined by each agent where an outcome might be valued in many different ways depending on personal aspirations (Ateca-Amestoy et al., 2008). Leisure activities may provide a wide variety of benefits such as experiences of competency, self-improvement, creativity and self-expression, self-fulfillment and personal meaning. Besides, leisure activities substantially appear in the active campus environment of students as a major component (Bloland, 1987). Further, students no longer consider academics as the only reason of selecting a university to attend with all the extracurricular activities provided (Woosnam et al., 2006), while satisfaction with these activities has an important impact on continued leisure participation during the university years (Elkins et al., 2007). Campus recreation programs facilitate developing or refining recreational skills and interests of students as well as their contribution to promoting school spirit, enabling student retention, and enhancing the quality of campus life (Weese, 1997). Student recreation centers are accepted as an essential component of student services on university campuses in which determining the crucial role of recreation in campus life may enable to improve quality of services. Service quality and user satisfaction measures are strongly associated with accountability, effectiveness, efficiency of various programs, and overall success of campus recreation centers (Osman et al., 2006). Particularly, recruitment and retention of students for higher education institutions are one of the main reasons for building student recreation centers (Watson II et al., 2006), in fact, higher education institutions are increasingly experience the possible impact of recreation facilities to compete for quality students (Hall, 2006). However, campus recreation assessment appears to be a necessary component to provide the better programs, services, facilities, and equipment to the campus community (Haines, 2010). In the meanwhile, campus recreation administrators are responsible for possible outcomes that provide evidence in regard with the relevant program's contribution to the mission of higher education institution (Cooper et al., 2009).

Pettigrew (1979) defines culture as "the system of publicly and collectively accepted meanings operating for a given group at a given time" (p. 574). In this sense, culture involves various capabilities of an individual as a member of society such as knowledge, belief, art, morals, law, custom, and others (Tylor, 1958). Organizational culture is defined as the collective programming of the mind that enables to distinguish the members of one organization from others (Hofstede et al., 2010). Organizational culture has some commonly-accepted characteristics as follows: holistic, historically determined, related to anthropological concepts, socially constructed, soft, and difficult to change (Hofstede et al., 1990). The organizational culture discourse is subsidiary to understand and analyze the main contributors that make a higher education institution getting structured (Lacatus, 2013). Particularly, higher education culture implies the cultural intermediary of a society in the corresponding institution which involves all cultural phenomena to define the characteristics of the institution such as commonly accepted values, the structure of the university's educational system, or behavior protocols (Shanggui, 2013). When students do not expect to take part in cultural events, collaborate with faculty members or study abroad, some opportunities to pursue these activities may be overlooked or dismissed out of hand (Kuh, 2009).

Campus recreational sports provides a service to offer students an opportunity to participate in sport and fitness activities through intramural, informal, or club sports, and fitness programs (Young et al., 2003; Lindsey \& Sessoms, 2006). Recreational sport facilities make significant contributions to increase overall satisfaction with the collegiate experience and higher education institution's retention efforts (Lindsey et al., 2009). Today, higher education institutions are increasingly recognizing the recreational sports programs as an important contributor for their mission in the campus life (Barcelona \& Rose, 2002). The aim of this present paper is to determine potential factors that influence undergraduate students' satisfaction with campus recreational sports and cultural facilities in a well-established Turkish state university. The determination of potential influencers may be thought as valuable information for future higher education mission. The rest of the paper proceeds as follows. Literature section reviews the selected earlier studies concerning the quality of campus life in terms of campus recreational sports and cultural facilities. Methodology section gives detailed information about the methodology being performed. Results section introduces and interprets the analysis results. The conclusion section discusses the analysis results with respect to their relevance to the existing literature and makes recommendation for future higher education institution policies and studies. 


\section{Review of Related Literature}

Studies concerning college students and quality of life can be divided into three categories such as studies investigating associations between students' quality of life and potential factors; studies developing students' measures of quality of life and studies developing measures of students' college life (Sirgy et al., 2007). In this section, the present study deals with past research that determines factors affecting students' quality of life. The current literature on the importance of student satisfaction abounds with a considerable number of examples. Prior studies (Kallio, 1995; Elliott \& Healy, 2001; Wilkins et al., 2012) suggest that students' overall experience is strongly associated with campus climate, student-centeredness, campus social life and institutional effectiveness. Recent studies (Aldemir \& Gülcan, 2004; Denson et al., 2010; Sojkin et al., 2012; de Jager and Gbadamosi, 2013; Sivis-Cetinkaya, 2013; Beck et al., 2014; Min \& Koon, 2014; Zhang et al., 2014) found that female students tended to have more satisfaction than male counterparts, whereas a most recent work (Sarrico \& Rosa, 2014) put forward that male students and freshmen were more satisfied groups. In Parahoo et al. (2013)'s study, reputation of higher education institution was a contributing factor for both male and female students, while academic competence was significant for only males. On the other hand, age was found (Aldemir \& Gülcan, 2004; Sojkin et al., 2012; Min \& Koon, 2014) as a crucial factor influencing students' satisfaction with higher education services. A number of studies (Kwan \& Ng, 1999; Mai, 2005; Gamage et al., 2008; Wilkins et al., 2012; de Jager \& Gbadamosi, 2013; Min \& Koon, 20014) accomplished several comparisons of student satisfaction between selected countries in various quality aspects. Another study (Moro-Egido \& Panades, 2010) found that students who hold a part-time job were more likely to have less satisfaction.

Gibson (2010) underlined the importance of quality of campus services on student satisfaction. Elkins et al. (2011) also indicated that participants of campus recreational sports had a greater sense of campus community. Prior studies (Terzioğlu \& Yazıcı, 2003; Müderrisoğlu et al., 2005) revealed that higher income students tended to more likely to participate in leisure activities. Martin (2012) found that social class is a significant indicator of participation in campus social life, where dominant class students were more involved in participate in campus social and recreational activities than middle and subordinate class students. Woosnam et al. (2006) showed that campus recreation facilities may be an influencer of attending a college. Similarly, Lai et al. (2014) found that social life was the most important indicator of students' college selection. Lindsey (2012) demonstrated that participating in campus recreational sports had a remarkable effect on their satisfaction with their academic experience and their experiences with other facilities. Henchy (2013) suggested that campus recreation facilities had a positive influence on students' life, though there were significant differences between participation of undergraduate and graduate students. Arslan and Altinbas-Akkas (2014) suggested that policy makers of higher education institutions might place their emphasis on the development of social services to increase students' satisfaction with campus life. Earlier studies (Frauman, 2005; Miller et al., 2008; Arslan, 2014) revealed that younger students were more likely to participate in campus recreational programs and services. On the contrary, other studies (Barcelona \& Ross, 2002; Young et al., 2003) indicated that older students were more likely to use campus recreational sports facilities. Lindsey and Sessoms (2006) found that female students were more likely to participate in campus recreational sports, while juniors and seniors consider these campus recreational programs as an important indicator of college selection. In contrast, some past research (Barcelona \& Ross, 2002; Terzioğlu \& Yazıcı, 2003; Young et al., 2003; Zizzi et al., 2004; Balc1 \& İlhan, 2006; Tekin et al., 2007; Miller et al., 2008; Lindsey et al., 2009; Lindsey, 2012; de Jager \& Gbadamosi, 2013) found that male students were more likely to be participants and other earlier studies (Watson II et al., 2006; Miller et al., 2008; Milton \& Patton, 2011) showed that lower-division students (freshmen and sophomores) were more likely to participate in campus recreational facilities. However, earlier research (Shank \& Beasley, 1998; Frauman, 2005; Clemes et al., 2008; Sökmen, 2011; Moosmayer \& Siems, 2012) indicated that there were no differences in the perceived importance of quality of campus life facilities with respect to students' gender. Marital status was also a contributing indicator, while results of a number of studies (Terzioğlu \& Yazıc1, 2003; Frauman, 2005; Miller et al., 2008) revealed that married students were less likely to participate in campus recreational programs. Several studies mentioned that off-campus (Barcelona \& Ross, 2002; Frauman, 2005) or on-campus students (Watson II et al., 2006; Miller et al., 2008; Milton \& Patton, 2011) and part-time employed students (Frauman, 2005) were more likely to participate in campus recreational sports programs. Nevertheless, some earlier studies (Aldemir \& Gülcan, 2003; Thomas \& Galambos, 2004) found that demographic factors did not have an effect on students' satisfaction with campus facilities.

\section{Method}

\subsection{Ordered Logit Model}

Special multivariate analysis for ordinal data seem to be a satisfactory alternative whenever it is obliged to 
control possible confounding factors or a consideration of several potential factors is required. Possible response of quality of life or satisfaction questionnaires on a generally Likert-type scale in five or seven points corresponds to an ordinal dependent variable with a single dimension (Abreu et al., 2008). Since the outcomes are clearly ordered, the researcher should consider the fact that the dependent variable is both ordinal and discrete. When the dependent variable shows these two characteristics simultaneously, ordered logit and probit models are the most frequently used and convenient methods to estimate models with more than two outcomes (Borooah, 2002).

The interpretation of the ordered logit model can be simply performed in terms of odds ratios for cumulative probabilities which also enable the model to have potentially greater power than ordinary multicategory logit models (Long, 1997; Agresti, 1996). Let $\left\{\pi_{1}, \pi_{2}, \ldots, \pi_{j}\right\}$ and $Y$ denote the response probabilities and a nominal variable with $j$ categories, respectively. Hence, for each possible $j$, the cumulative probabilities represent the corresponding probabilities where the response $Y$ falls in category $j$ or below. In that sense, the $j$ th cumulative probability is shown as the following (Agresti, 1996):

$$
P(Y \leq j)=\pi_{1}+\ldots+\pi_{j} \quad j=1, \ldots, J
$$

The conditional probabilities for the ordered outcomes with respect to the cumulative probabilities can be determined as

$$
\operatorname{Pr}\left(y_{i}=j \mid x_{i}\right)= \begin{cases}F\left(\alpha_{1}+x_{i}^{\prime} \beta\right) & j=1 \\ F\left(\alpha_{j}+x_{i}^{\prime} \beta\right)-F\left(\alpha_{j-1}+x_{i}^{\prime} \beta\right) & 1<j \leq J-1 \\ 1-F\left(\alpha_{J-1}+x_{i}^{\prime} \beta\right) & j=J\end{cases}
$$

which enable to retrieve the predicted probabilities from the model related to a response (Power \& Xie, 2000). Since $j=1, \ldots, J-1$, the logits of the first $J-1$ cumulative probabilities can be given as

$$
\operatorname{logit}[P(Y \leq j)]=\log \left(\frac{P(Y \leq j)}{1-P(Y \leq j)}\right)=\log \left(\frac{\pi_{1}+\ldots+\pi_{j}}{\pi_{j+1}+\ldots+\pi_{J}}\right)
$$

which are called cumulative logits. Ordinal models allow a framework for all $J-1$ cumulative logits. For instance, when $J=3$, models are able to explain both $\log \left[\pi_{1} /\left(\pi_{2}+\pi_{3}\right)\right]$ and $\log \left[\left(\pi_{1}+\pi_{2}\right) / \pi_{3}\right]$ simultaneously. Suppose that $X$ denotes a predictor and $j=1, \ldots, J-1$, the proportional odds model can be introduced as

$$
\operatorname{logit}[P(Y \leq j)]=\alpha_{j}+\beta_{x}
$$

where $\beta$ parameter describes the effect of $X$ on the log odds of response in category $j$ or below. For the collapsed response scale, the model can be interpreted using odds ratios. The log of odds ratios are the differences between the cumulative logits at various values of $x$. Due to the proportional property, the model in Equation (4) refers to a proportional odds model. Particularly, for $x_{2}-x_{1}=1$, the odds of response below any given category multiply by $e^{\beta}$ for each unit increase in $X$ and since the model holds with $\beta=0$, then $X$ and $Y$ are statistically independent (Agresti, 1996).

Maximum likelihood estimation of parameters for the ordered probability models purposes to explore the estimates of $a_{j}$ 's and $\beta$ 's that maximize the joint probability of obtaining the observed values. For each of the $J$ values of the ordered response, the likelihood can be written as

$$
L=\prod_{i=1}^{n} \prod_{j=1}^{J} \operatorname{Pr}\left(y_{i}=j \mid x_{i}\right)^{d_{i j}}
$$

where $d_{i j}=1$ if $y_{i}=j$, and 0 otherwise. Hence, for any observation, the $d_{i j}$ refer to a set of $J$ dummy variables, only one of which equals to 1 . The log-likelihood with respect to model quantities for the cumulative logit and probit models is given by as follows (Powers \& Xie, 2000): 


$$
\log L=\sum_{i=1}^{n} \sum_{j=1}^{J} d_{i j} \log \left[F\left(\alpha_{j}+x_{i}^{\prime} \beta\right)-F\left(\alpha_{j-1}+x_{i}^{\prime} \beta\right)\right]
$$

The parallel regression or proportional odds assumption is a critical assumption of the ordered logit and probit models. It proposes that if there is a variable which influences the likelihood of an event being in the ordered categories then it is assumed that the coefficients linking the variable value to the different outcomes will be the same across all the outcomes (Borooah, 2002). Since $\tau$ 's are thresholds or cut points, Equation (1) can be re-written as

$$
\operatorname{Pr}(y \leq m \mid x)=F\left(\tau_{m}-x \beta\right)
$$

for $m=1$ to $J-1$. Equation (7) shows that ordinal regression model is analogous to $J-1$ binary regressions with the critical assumption that the slope coefficients are identical across each regression. The parallel regression assumption can be tested through a comparison among the estimate from the $J-1$ binary regressions:

$$
\operatorname{Pr}(y \leq m \mid x)=F\left(\tau_{m}-x \beta_{m}\right)
$$

In Equation (8), the model enables the $\beta$ 's to differ across equations. So, the parallel regression assumption implies that $\beta_{1}=\beta_{2}=\ldots=\beta_{J-1}$. In that manner, the estimated coefficients should be close to satisfy the parallel regression assumption. A Wald test proposed by Brant (1990) provides a test procedure of parallel regression assumption for individual variables that overcomes the likelihood ratio test (Long \& Freeze, 2001).

\subsection{Study Design, Sample and Data Collection}

The study was conducted between October and March 2012 on a university campus located in Erzurum, northeast of Turkey which offers a variety of campus recreational sports and cultural services including football stadium, multi-purpose sports center, bowling/pool hall, gym, tennis court, and movie theater, etc. Established in 1957, Atatürk University is one of the leading universities in Turkey with respect to the number of students and experienced academic staff. It is the seventh oldest university in the country (D. Günay \& A. Günay, 2011). The study utilized the data from a self-administered and written-questionnaire which was distributed to 1,000 undergraduate students. The corresponding survey performs a stratified sampling method in parallel with the number of students to keep the level of representation both proportional and as high as possible. The Cronbach alpha value was found as 0.767 satisfying the minimum 0.70 recommended by Nunnally (1978) for relatively high internal consistency. The questionnaire involved detailed questions about both respondents' campus recreational sports and cultural facilities participation and their demographic background. According to the statistics of Selection and Placement Center of Turkey (OSYM, 2012), the total number of undergraduate students in Atatürk University during the sample period was 35,604. The minimum sample size of the questionnaire was calculated with respect to the following formula

$$
n=\frac{N P Q Z^{2}}{(N-1) d^{2}+P Q Z^{2}}
$$

where $n$ denotes the sample size; $N$ denotes the population size; $P=$ the probability of the occurrence for a given event; $Q=1-P ; Z$ denotes the test statistic under the $(1-\alpha) \%$ significance level; and finally $d$ denotes the tolerance. In this respect, the minimum representative sample size of the survey can be calculated as follows (Özer, 2004):

$$
n=\frac{(35,604)(0.5)(0.5)(1.96)^{2}}{(35,604-1)(0.05)^{2}+(0.5)(0.5)(1.96)^{2}} \cong 380
$$

As shown in Equation (10), 1,000 respondents exceed the number of minimum sample size.

\section{Results}

\subsection{Descriptive Statistics}

Table 1 indicates the descriptive statistics of variables used in the fitted model. Almost half of the respondents (48.4\%) were generally dissatisfied with campus recreational sports and cultural activities and dramatically only $3.4 \%$ of them were very satisfied with these facilities. As shown in Table 1, almost half of the respondents $(50.4 \%)$ were female students and almost $37 \%$ of them $(37.4 \%)$ were aged between twenty and twenty one. More than half of the respondents $(63.5 \%)$ were studying in social sciences or educational sciences and more 
than half of them (55\%) were freshmen or juniors. Considering the monthly education loan during the sample period was 300 Turkish Liras (TL), nearly $40 \%$ of the respondents (40.6\%) had more than 400 TL monthly expense, while more than half of them had an additional educational $(52.7 \%)$ or a tutition loan $(57 \%)$ from the goverment, respectively. Regarding the type of music that the respondents listening, almost $38 \%$ of the respondents $(37.6 \%)$ have declared that they did not listen any regular kind of music, while classical/folk songs (24.7\%) and popular music (23.4\%) came second and third, respectively. The respondents generally prefer to spend with their friends (39.5\%) as a leisure time activity, while reading (14.\%) and sports activities (12.9\%) were their second choice. It was noteworthy that cultural activities $(8 . \%)$ were their least preference to spend their leisure time.

Table 1. Descriptive statistics of variables

\begin{tabular}{|c|c|c|c|c|c|}
\hline Variable & Frequency & Percent & Variable & Frequency & Percent \\
\hline Gender & & & Type of music & & \\
\hline Male & 496 & 49.60 & Popular & 234 & 23.40 \\
\hline Female & 504 & 50.40 & Rock/metal & 141 & 14.10 \\
\hline Age group & & & Classical/Folk songs & 247 & 24.70 \\
\hline $18-19$ & 165 & 16.50 & Any kind of music & 376 & 37.60 \\
\hline $20-21$ & 374 & 37.40 & Tuition loan & & \\
\hline $22-23$ & 287 & 28.70 & Yes & 430 & 43.00 \\
\hline 24 and older & 174 & 17.40 & No & 570 & 57.00 \\
\hline Faculty & & & Educational loan & & \\
\hline Social sciences & 395 & 39.50 & Yes & 473 & 47.30 \\
\hline Applied sciences & 249 & 24.90 & No & 527 & 52.70 \\
\hline Health sciences & 86 & 8.60 & Leisure time activity & & \\
\hline Educational sciences & 270 & 27.00 & Watching TV & 134 & 13.40 \\
\hline Class standing & & & Sports activities & 129 & 12.90 \\
\hline Freshman & 287 & 28.70 & Reading & 140 & 14.00 \\
\hline Sophomore & 227 & 22.70 & Cultural activities & 80 & 8.00 \\
\hline Junior & 263 & 26.30 & Web browsing & 122 & 12.20 \\
\hline Senior/Super senior & 223 & 22.30 & Spending time with friends & 395 & 39.50 \\
\hline Monthly expense & & & General satisfaction & & \\
\hline $200 \mathrm{TL}$ and less & 214 & 21.40 & Very dissatisfied & 220 & 22.00 \\
\hline $201 \mathrm{TL}-400 \mathrm{TL}$ & 380 & 38.00 & Dissatisfied & 264 & 26.40 \\
\hline \multirow[t]{3}{*}{ More than $400 \mathrm{TL}$} & 406 & 40.60 & Neutral & 244 & 24.40 \\
\hline & & & Satisfied & 238 & 23.80 \\
\hline & & & Very satisfied & 34 & 3.40 \\
\hline
\end{tabular}

Table 2 gives satisfaction level for selected responses. As shown in Table 2, almost 39\% and 35\% of the respondents were very dissatisfied or dissatisfied with facilities for cultural (38.5\%) and sports $(35.2 \%)$ activities on campus, respectively. Their dissatisfaction arises for the announcement for these activities when the relevant percentage increases to $55.2 \%$ for cultural and $53.1 \%$ for sports activities. Moreover, more than $40 \%$ of the respondents were not generally satisfied with courtesy of facility workers and in parallel, they also do not think that managers conscientiously pay attention for campus sports with relatively high (almost $45 \%$ ) dissatisfaction scores. The survey also investigates the students' opinions on the spring festival. Similarly, relatively higher dissatisfaction scores for schedule (46.8\%), place $(52.5 \%)$, general organization $(47.5 \%)$, and campus security $(52.1 \%)$ of the spring festival suggest a significant improvement for this facility. 
Table 2. Frequencies and percentages for the respondents' satisfaction levels of selected campus facilities

\begin{tabular}{|c|c|c|c|c|c|c|c|c|c|c|}
\hline \multirow{3}{*}{ Satisfaction with } & \multicolumn{10}{|c|}{ Satisfaction Level } \\
\hline & \multicolumn{2}{|c|}{$\begin{array}{c}\text { Very } \\
\text { dissatisfied }\end{array}$} & \multicolumn{2}{|c|}{ Dissatisfied } & \multicolumn{2}{|c|}{ Neutral } & \multicolumn{2}{|c|}{ Satisfied } & \multicolumn{2}{|c|}{ Very satisfied } \\
\hline & Freq. & Percent & Freq. & Percent & Freq. & Percent & Freq. & Percent & Freq. & Percent \\
\hline Facilities for cultural activities & 137 & 13.70 & 248 & 24.80 & 254 & 25.40 & 324 & 32.40 & 37 & 3.70 \\
\hline $\begin{array}{l}\text { Announcement for cultural } \\
\text { activities }\end{array}$ & 240 & 24.00 & 312 & 31.20 & 195 & 19.50 & 225 & 22.50 & 28 & 2.80 \\
\hline Facilities for sports activities & 132 & 13.20 & 220 & 22.00 & 288 & 28.80 & 318 & 31.80 & 42 & 4.20 \\
\hline $\begin{array}{l}\text { Announcement for sports } \\
\text { activities }\end{array}$ & 229 & 22.90 & 302 & 30.20 & 207 & 20.70 & 216 & 21.60 & 46 & 4.60 \\
\hline Courtesy of facility workers & 209 & 20.90 & 195 & 19.50 & 321 & 32.10 & 236 & 23.60 & 39 & 3.90 \\
\hline $\begin{array}{l}\text { Managers' attention for sports } \\
\text { and cultural activities }\end{array}$ & 192 & 19.20 & 257 & 25.70 & 243 & 24.30 & 233 & 23.30 & 75 & 7.50 \\
\hline $\begin{array}{l}\text { Required equipment of } \\
\text { university for sports and } \\
\text { cultural activities }\end{array}$ & 164 & 16.40 & 256 & 25.60 & 286 & 28.60 & 233 & 23.30 & 61 & 6.10 \\
\hline Schedule of the spring festival & 303 & 30.30 & 165 & 16.50 & 186 & 18.60 & 225 & 22.50 & 121 & 12.10 \\
\hline Place of the spring festival & 269 & 26.90 & 256 & 25.60 & 273 & 27.30 & 159 & 15.90 & 43 & 4.30 \\
\hline $\begin{array}{l}\text { General organization of the } \\
\text { spring festival }\end{array}$ & 240 & 24.0 & 239 & 23.90 & 278 & 27.80 & 191 & 19.10 & 52 & 5.20 \\
\hline $\begin{array}{l}\text { Campus security during the } \\
\text { spring festival }\end{array}$ & 296 & 29.60 & 225 & 22.50 & 260 & 26.00 & 165 & 16.50 & 54 & 5.40 \\
\hline
\end{tabular}

Table 3 presents the respondents' agreement levels on selected statements concerning campus sports and cultural facilities. Almost 39\% of the respondents (38.50\%) declared that sports and cultural activities on campus did not generally meet their expectations. On the other hand, more than half of them $(58.40 \%)$ did not complain about a public-open campus. $40 \%$ of the respondents claimed that they did not have enough leisure time for sports and cultural activities, while almost half of them (48.50\%) did not participate in campus sports and cultural activities. More than half of the respondents $(55.40 \%)$ thought that sports and cultural activities were not organized for their interests and skills and almost $64 \%$ of them felt that university managers did not consider their views on these activities. The respondents expect a much modern campus claiming their opinions on modern museum (73.5\%), theater $(78.4 \%)$, and sports center $(75.2 \%)$ agreement. They also anticipate a more competitive $(73.2 \%)$ campus sports facilities to host various sport events (75.2\%) among different universities. The respondents definitely underline the role of voluntary sports and cultural clubs $(81.7 \%)$ on improving sports and cultural activities on their campus.

Table 3. Frequencies and percentages for the respondents' opinions of campus sports and cultural facilities

\begin{tabular}{|c|c|c|c|c|c|c|c|c|c|c|}
\hline \multirow{3}{*}{ Statement } & \multicolumn{10}{|c|}{ Agreement Level } \\
\hline & \multicolumn{2}{|c|}{$\begin{array}{l}\text { Definitely } \\
\text { disagree }\end{array}$} & \multicolumn{2}{|c|}{ Disagree } & \multicolumn{2}{|c|}{ Neutral } & \multicolumn{2}{|c|}{ Agree } & \multicolumn{2}{|c|}{$\begin{array}{l}\text { Definitely } \\
\text { agree }\end{array}$} \\
\hline & Freq. & Percent & Freq. & Percent & Freq. & Percent & Freq. & Percent & Freq. & Percent \\
\hline $\begin{array}{l}\text { "My expectations meet with } \\
\text { campus sports and cultural } \\
\text { activities" }\end{array}$ & 140 & 14.0 & 245 & 24.50 & 331 & 33.10 & 246 & 24.6 & 38 & 3.80 \\
\hline $\begin{array}{l}\text { "Sports and cultural activities } \\
\text { should not be public-open" }\end{array}$ & 410 & 41.0 & 174 & 17.40 & 72 & 7.20 & 151 & 15.10 & 193 & 19.30 \\
\hline
\end{tabular}




\begin{tabular}{lccccccccccc}
\hline $\begin{array}{l}\text { "I have enough leisure time } \\
\text { for sports and cultural } \\
\text { activities }\end{array}$ & 143 & 14.30 & 257 & 25.70 & 369 & 36.90 & 149 & 14.90 & 82 & 8.20 \\
$\begin{array}{l}\text { "Sports and cultural activities } \\
\text { match with my interests and } \\
\text { skills" }\end{array}$ & 258 & 25.80 & 296 & 29.60 & 292 & 29.20 & 122 & 12.20 & 32 & 3.20 \\
$\begin{array}{l}\text { "I participate in campus sports } \\
\text { and cultural activities" }\end{array}$ & 244 & 24.40 & 241 & 24.10 & 323 & 32.30 & 117 & 11.70 & 75 & 7.50 \\
$\begin{array}{l}\text { "University takes my } \\
\text { complaints and suggestions } \\
\text { into consideration on sports }\end{array}$ & 350 & 35.0 & 289 & 28.90 & 255 & 25.50 & 68 & 6.80 & 38 & 3.80 \\
$\begin{array}{l}\text { and cultural activities" } \\
\text { "University should build a } \\
\text { modern museum" }\end{array}$ & 49 & 4.90 & 56 & 5.60 & 160 & 16.0 & 272 & 27.20 & 463 & 46.30 \\
$\begin{array}{l}\text { "University should build a } \\
\text { modern theater" }\end{array}$ & 43 & 4.30 & 63 & 6.30 & 110 & 11.0 & 279 & 27.90 & 505 & 50.5 \\
$\begin{array}{l}\text { "University should provide } \\
\text { modern facilities for more } \\
\text { advanced sports competitions }\end{array}$ & 52 & 5.20 & 72 & 7.20 & 144 & 14.40 & 271 & 27.10 & 461 & 46.10 \\
$\begin{array}{l}\text { "University should host sports } \\
\text { competitions among different } \\
\text { universities" }\end{array}$ & 93 & 9.30 & 72 & 7.20 & 83 & 8.30 & 282 & 28.20 & 470 & 47.0 \\
"Voluntary sports and cultural \\
$\begin{array}{l}\text { clubs should work more } \\
\text { effectively" }\end{array}$
\end{tabular}

\subsection{Estimation Results}

Table 4 indicates the ordered logit model estimation results to determine the influencing factors of student satisfaction with campus recreational and cultural activities. The dependent variable of this study was the students' overall satisfaction with campus recreational sports and cultural facilities, which was ordinal in nature, where 1, 2, 3, 4, and 5 stand for 'very dissatisfied', 'dissatisfied', 'neutral', 'satisfied', and 'very satisfied', respectively. Therefore, an ordered logit model was used to analyze the impact of independent variables on the underlying dependent variable in Stata 11.2. Dummy variables were used in the statistical model to illustrate the estimation results regarding five categories. The model was statistically significant at $99 \%$ level of significance and fitted well with very small values of Akaike and Bayesian Information Criteria. The interpretation of the estimates was performed using the corresponding odds ratios (OR). Accordingly, age was a significant factor affecting campus sports and cultural facilities satisfaction, while holding all other variables constant, the odds of very satisfied versus the combined satisfaction levels were 0.69 times $(\mathrm{OR}=0.69, p<.05,95 \% \mathrm{CI}=047-1.00)$ lower than other age groups. Likewise, the odds of the combined categories of very satisfied, satisfied, neutral, and dissatisfied versus very dissatisfied were 0.69 time lower for other age groups, given the other variables were held constant in the model. Similarly, the fitted model suggests that the odds of very satisfied social sciences students were 0.74 times $(\mathrm{OR}=0.74, p<.05,95 \% \mathrm{CI}=0.56-0.98)$ lower than other faculty categories. Relatively higher income students were found as less likely to be satisfied than other income categories, holding other variables constant, since the odds of respondents who had more than $400 \mathrm{TL}$ monthly income were 0.63 times $(\mathrm{OR}=0.63, p<.01,95 \% \mathrm{CI}=0.46-0.87)$ lower than the combined other income levels. Classical or folk music listeners were less likely to be satisfied than the combined other types of music, while the odds of these respondents were 0.67 times $(\mathrm{OR}=0.67, p<.01,95 \% \mathrm{CI}=0.50-0.91)$ lower than the combined categories. Finally, the odds of tuition loan holders were 0.78 times $(\mathrm{OR}=0.78, p<.05,95 \% \mathrm{CI}=0.61-0.99)$ lower than non-holders. 
Table 4. Ordered logit model estimation of the factors affecting student satisfaction with campus recreational sports and cultural facilities

\begin{tabular}{|c|c|c|c|c|c|}
\hline Independent variable & OR & Std. Err. & $\mathbf{z}$ & Sig. & {$[95 \% \mathrm{CI}]$} \\
\hline \multicolumn{6}{|l|}{ Gender } \\
\hline Female & 1.09 & 0.134 & 0.70 & 0.484 & $0.86, \quad 1.39$ \\
\hline \multicolumn{6}{|c|}{ Age group (base 24 and older) } \\
\hline $18-19$ & 0.94 & 0.226 & -0.26 & 0.794 & $0.59, \quad 1.50$ \\
\hline $20-21$ & 0.69 & 0.132 & -1.96 & $0.049^{* *}$ & $0.47, \quad 1.00$ \\
\hline $22-23$ & 0.79 & 0.138 & -1.36 & 0.174 & $0.56, \quad 1.11$ \\
\hline \multicolumn{6}{|c|}{ Faculty (base Educational sciences) } \\
\hline Social sciences & 0.74 & 0.107 & -2.07 & $0.039^{* *}$ & $0.56, \quad 0.98$ \\
\hline Applied sciences & 0.78 & 0.125 & -1.56 & 0.118 & $0.57, \quad 1.07$ \\
\hline Health sciences & 0.79 & 0.182 & -1.02 & 0.306 & $0.50, \quad 1.24$ \\
\hline \multicolumn{6}{|c|}{ Year of education (base Freshman) } \\
\hline Sophomore & 0.86 & 0.148 & -0.90 & 0.368 & $0.61,1.21$ \\
\hline Junior & 0.94 & 0.171 & -0.34 & 0.732 & $0.66, \quad 1.34$ \\
\hline Senior/Super senior & 0.83 & 0.171 & -0.90 & 0.370 & $0.56, \quad 1.24$ \\
\hline \multicolumn{6}{|c|}{ Monthly expense (base 200 TL and less) } \\
\hline $201 \mathrm{TL}-400 \mathrm{TL}$ & 0.78 & 0.123 & -1.56 & 0.119 & $0.58,1.06$ \\
\hline More than $400 \mathrm{TL}$ & 0.63 & 0.104 & -2.78 & $0.005^{*}$ & $0.46, \quad 0.87$ \\
\hline \multicolumn{6}{|c|}{ Type of music (base Any kind of music) } \\
\hline Pop & 1.13 & 0.171 & 0.79 & 0.428 & $0.84,1.52$ \\
\hline Rock/metal & 0.77 & 0.136 & -1.46 & 0.144 & $0.55, \quad 1.09$ \\
\hline Classical/Folk songs & 0.67 & 0.101 & -2.62 & $0.009^{*}$ & $0.50, \quad 0.91$ \\
\hline \multicolumn{6}{|l|}{ Tuition loan } \\
\hline Yes & 0.78 & 0.098 & -2.02 & $0.044 * *$ & $\begin{array}{ll}0.61, & 0.99\end{array}$ \\
\hline \multicolumn{6}{|l|}{ Educational loan } \\
\hline Yes & 0.99 & 0.124 & -0.05 & 0.963 & $0.78, \quad 1.27$ \\
\hline$/$ cut1 & -2.27 & 0.292 & & & \\
\hline /cut2 & -1.03 & 0.284 & & & \\
\hline /cut3 & 0.06 & 0.283 & & & \\
\hline /cut4 & 2.45 & 0.322 & & & \\
\hline
\end{tabular}

Number of observations: 1000

Log-likelihood full model: -1464.658

Log-likelihood intercept only: -1485.501

LR chi-square(17): 41.69

Prob. > chi-square: 0.0007

$\rho^{2}: 0.067$

Akaike Information Criterion: 2.971

Bayesian Information Criterion: -3833.377

*significant at $99 \%$; * significant at $95 \%$.

\subsection{Model Specification}

Table 5 indicates the parallel regression assumption proposed by Brant (1990). Since the null hypothesis is that there is no difference in the coefficients between models, a non-significant result guarantees that the parallel regression assumption is not violated. Since both the overall significance $\left(\chi^{2}=57.75, p>.05, \mathrm{df}=51\right)$ and all other significance levels in Table 1 were higher than $95 \%$ level of significance, the estimation results of the fitted model was statistically sound. 
Table 5. Brant test of parallel regression assumption

\begin{tabular}{lrrl}
\hline Independent variable & Chi-square & Sig. & d.f. \\
\hline All & 57.75 & 0.240 & 51 \\
\hline Gender & & & \\
$\quad$ Female & 7.16 & 0.067 & 3 \\
Age group & & & \\
$\quad$ 18-19 & 0.93 & 0.819 & 3 \\
$20-21$ & 3.23 & 0.358 & 3 \\
22-23 & 0.82 & 0.845 & 3 \\
Faculty & & & \\
$\quad$ Social Sciences & 4.27 & 0.234 & 3 \\
$\quad$ Health Sciences & 0.44 & 0.932 & 3 \\
$\quad$ Applied Sciences & 2.30 & 0.512 & 3 \\
$\quad$ Year of education & & & \\
$\quad$ Sophomore & 4.68 & 0.197 & 3 \\
$\quad$ Junior & 5.59 & 0.133 & 3 \\
$\quad$ Senior/Super senior & 10.81 & 0.013 & 3 \\
Monthly expense & & & \\
$\quad$ 201 TL-400 TL & 1.90 & 0.593 & 3 \\
$\quad$ More than 400 TL & 0.68 & 0.877 & 3 \\
Type of music & & & \\
$\quad \begin{array}{l}\text { Pop } \\
\text { Rock/metal } \\
\quad \text { Classical/Folk songs }\end{array}$ & 3.65 & 0.302 & 3 \\
$\quad \begin{array}{l}\text { Tuition loan } \\
\text { Yes } \\
\text { Educational loan }\end{array}$ & 0.25 & 0.969 & 3 \\
$\quad$ Yes & 4.76 & 0.190 & 3 \\
\hline
\end{tabular}

Table 6 exhibits the variance inflation factor (VIF) values of the relevant independent variables included in the fitted ordered logit model. Practically, variables which have VIF values more than 10 are considered as they lead to multicollinearity problem and biased results. As shown in Table 6, none of the independent variables had VIF values more than 10 confirming the absence of multicollinearity in the data.

Table 6. Multicollinearity test

\begin{tabular}{lcc}
\hline Independent variable & VIF & $\mathbf{1 / V I F}$ \\
\hline $\begin{array}{l}\text { Gender } \\
\text { Female }\end{array}$ & 1.18 & 0.846 \\
$\quad$ Age group & & \\
$\quad 18-19$ & 2.49 & 0.401 \\
$20-21$ & 2.70 & 0.370 \\
$22-23$ & 2.01 & 0.497 \\
Faculty & & \\
$\quad$ Social Sciences & 1.54 & 0.648 \\
$\quad$ Health Sciences & 1.53 & 0.652 \\
$\quad$ Applied Sciences & 1.51 & 0.761 \\
$\quad$ Year of education & & \\
$\quad$ Sophomore & 1.59 & 0.629 \\
$\quad$ Junior & 1.94 & 0.515 \\
$\quad$ Senior/Super senior & 2.29 & 0.437 \\
$\quad$ Monthly expense & & \\
$\quad$ 201 TL - 400 TL & 1.80 & 0.555 \\
$\quad$ More than 400 TL & 1.98 & 0.504 \\
Type of music & & \\
\hline
\end{tabular}




\begin{tabular}{lll}
\hline Pop & 1.27 & 0.787 \\
Rock/metal & 1.20 & 0.835 \\
$\quad$ Classical/Folk songs & 1.30 & 0.768 \\
$\quad$ Tuition loan & & \\
$\quad$ Yes & 1.24 & 0.810 \\
$\quad$ Educational loan & & \\
$\quad$ Yes & 1.23 & 0.812 \\
Mean VIF & 1.68 & \\
\hline
\end{tabular}

\section{Discussion}

The main purpose of this paper was to assess student satisfaction in a well-known Turkish university with a particular focus on campus recreational sports and cultural activities. Though Atatürk University takes its respectable place on Turkish higher education system in terms of its experience and wide student network, facility management of this university has not been investigated in detail. Moreover, the number of specific studies exploring campus recreational sports and cultural activities is not satisfactory. In this context, this paper intends to fill the underlying gap in the service quality literature. Additionally, this paper attempts to determine the influencing demographic and socio-economic factors on campus sports and cultural activities satisfaction. Probably, this is the first effort to use a categorical data analysis method to give the detailed facility satisfaction determinants in Turkey.

The descriptive statistics indicated that about half of the students were generally very dissatisfied with campus sports and cultural services. Many studies which were carried out in Turkish sample (Terzioğlu \& Yazıc1, 2003; Aldemir \& Gülcan, 2004; Balc1 \& İlhan, 2006; Tekin et al., 2011; Sabbah \& Aksoy, 2011; Sökmen, 2011; Arslan, 2014; Arslan \& Altinbas-Akkas, 2014) also put forward similar dissatisfaction and underlined the importance of improving the facilities on campus climate and student retention. In this study, age group was a significant determinant of student satisfaction with campus sports and cultural facilities. This result is consistent with much earlier work (Barcelona \& Ross, 2002; Young et al., 2003; Frauman, 2005; Miller et al., 2008; Arslan, 2014). However, gender was not found a statistically significant determinant of students' campus sports and cultural facility satisfaction in accordance with some selected studies (Shank \& Beasley, 1998; Frauman, 2005; Clemes et al., 2008; Sökmen, 2011, Moosmayer \& Siems, 2012) in the literature. In contrast to some earlier studies (Terzioğlu \& Yazıcı, 2003; Müderrisoğlu et al., 2005), the results in the present study indicated higher income students were less likely to have higher satisfaction. The estimation results also mentioned that students' who had tuition loan were more likely to have higher dissatisfaction. As stated earlier, a number of students think of that sports and cultural activities on campus do not meet their expectations and match their interests and skills. So, following a low level of participation in campus sports and cultural facilities, higher income students and tuition loan holders might have tended to seek off-campus organizations as an alternative leisure time activity. One noteworthy result was higher dissatisfaction of students of social sciences relative to other faculties. On the other hand, classical or folk music listeners were another significant dissatisfied group. Managers of campus sports and cultural facilities may consider on organizing more attractive cultural organizations especially during the spring festivals concentrating on classic or folk music singers. They may also organize the spring festivals in a more specialized and modern concert arena instead of football stadium. The decision- and policy makers should pay attention to take students' opinions and affairs for student retention and they may tend to plant more cultural facility places including modern museums and theaters. Herein, voluntary sports and cultural student club officials may moderate the communication between managers and students. Further, it can be suggested that attracting higher income groups may facilitate to contribute the economy on campus.

The results also indicated that students expect a more competitive campus in terms of sport events. Erzurum is one of the most crucial city in its region acting as a bridge from the east to the west. Considering its geographic position, it is definitely able to host respectable sport events among universities in the region. Especially, following the experience of Winter Universiade 2011, hosted in the city, managers of campus sport facilities may consult with organizers to take assistance of their experiences on improving sport facilities on campus, especially for winter sports. This study was limited to only one university campus in a limited time schedule. Further similar or distinctive studies with an emphasis on campus sports and cultural activities may be performed including all other university campus in the region for a detailed comparison of student satisfaction. The increased number of annual studies in the region may be an important control mechanism for increasing student retention, decreasing student dropout, and improved campus climate, culture and facilities. In addition, further research may provide a comparison of other ordered response models such as generalized ordered logit model, 
heterogeneous choice model or partial constrained generalized ordered logit model.

\section{References}

Abreu, M. N. S., Siqueira, A. L., Cardoso, C. S., \& Caiaffa, W. T. (2008). Ordinal logistic regression models: Application in quality of science studies. Cad Saude Publica, 24(4), 581-591. http://dx.doi.org/10.1590/S0102-311X2008001600010

Agresti, A. (1996). An introduction to categorical data analysis. New York: John Wiley \& Sons, Inc.

Aldemir, C., \& Gülcan, Y. (2004). Student satisfaction in higher education: A Turkish case. Higher Education Management and Policy, 16(2), 109-122. http://dx.doi.org/10.1787/hemp-v16-art19-en

Aldridge, S., \& Rowley, J. (1998). Measuring customer satisfaction in higher education. Quality Assurance in Education, 6(4), 197-204. http://dx.doi.org/10.1108/09684889810242182

Appleton-Knapp, S. L., \& Krentler, K. A. (2006). Measuring student expectations and their effects on satisfaction: The importance of managing student expectations. Journal of Marketing Education, 28(3), 254-264. http://dx.doi.org/10.1177/0273475306293359

Arambewela, R., \& Hall, J. (2009). An empirical model of international student satisfaction. Asia Pasific Journal of Marketing and Logistics, 21(4), 555-569. http://dx.doi.org/10.1108/13555850910997599

Arslan, H. (2014). Üniversite öğrencilerinin boş zaman değerlendirme tercihleri: Çankırı Karatekin Üniversitesi Örneği (in Turkish). Dumlupinar Üniversitesi Sosyal Bilimler Dergisi, 40, 193-208. Retrieved from http://birimler.dpu.edu.tr/app/views/panel/ckfinder/userfiles/17/files/DERG_/40/2004.pdf

Arslan, S., \& Altinbas-Akkas, O. (2014). Quality of college life (QCL) of students in Turkey: Students' life satisfaction and identification. Social Indicators Research, 115(2), 869-884. http://dx.doi.org/10.1007/s11205-013-0235-9

Ateca-Amestoy, V., Serrano-del-Rosal, R., \& Vera-Toscano, E. (2008). The leisure experience. The Journal of Socio-Economics, 37(1), 64-78. http://dx.doi.org/10.1016/j.socec.2006.12.025

Balc1, V., \& İlhan, A. (2006). Türkiye'deki üniversite öğrencilerinin rekreatif etkinliklere katılım düzeylerinin belirlenmesi (in Turkish), SPORMETRE Beden Eğitimi ve Spor Bilimleri Dergisi, 4(1), 11-18. Retrieved from http://dergiler.ankara.edu.tr/dergiler/17/891/11185.pdf

Barcelona, R. J., \& Ross, C. M. (2002). Participation patterns in campus recreational sports: An examination of quality of student effort from 1983 to 1998". Recreational Sports Journal, 26(1), 41-53.

Beck, D. E., Maranto, R., \& Lo, W. J. (2014). Determinants of student and parent satisfaction at a cyber charter school. The Journal of Education Research, 107(3), 209-216. http://dx.doi.org/10.1080/00220671.2013.807494

Benckendorff, P., Ruhanen, L., \& Scott, N. (2009). Deconstructing the student experience: A conceptual framework. Journal of Hospitality and Tourism Management, 16(1), 84-93. http://dx.doi.org/10.1375/jhtm.16.1.84

Bloland, P. A. (1987). Leisure as a campus resource for fostering student development. Journal of Counseling and Development, 65(6), 291-294. http://dx.doi.org/10.1002/j.1556-6676.1987.tb01288.x

Borooah, V. K. (2002). Logit and probit: Ordered and multinomial models. Thousand Oaks, California: SAGE Publications.

Brant, R. (1990). Assessing proportionality in the proportional odds model for ordinal logistic regression. Biometrics, 46(4), 1171-1178. http://dx.doi.org/10.2307/2532457

Clemes, M. D., Gan, C. E. C., \& Kao, T. H. (2008). University student satisfaction: An empirical analysis. Journal of Marketing for Higher Education, 17(2), 292-325. http://dx.doi.org/10.1080/08841240801912831

Cooper, N., Flood, J., \& Gardner, E. (2009). Establishing a learning outcomes plan for campus recreation. Recreational Sports Journal, 33(1), 12-24.

De Jager, J., \& Gbadamasi, G. (2013). Predicting students' satisfaction through service quality in higher education. The International Journal of Management Education, 11(3), 107-118. http://dx.doi.org/10.1016/j.ijme.2013.09.001

Denson, N., Loveday, T., \& Dalton, H. (2010). Student evaluation of courses: What predicts satisfaction? Higher Education Research and Development, 29(4), 339-356. http://dx.doi.org/10.1080/07294360903394466 
Elkins, D. J., Beggs, B. A., \& Choutka, E. (2007). The contribution of constraint negotiation to the leisure satisfaction of college students in campus recreational sports. Recreational Sports Journal, 31(2), 107-118.

Elkins, D. J., Forrester, S. A., \& Noël-Elkins, A. V. (2011). The contribution of campus recreational sports participation to perceived sense of campus community. Recreational Sports Journal, 35(1), 24-34.

Elliott, K. M., \& Healy, M. A. (2001). Key factors influencing student satisfaction related to recruitment and retention. Journal of Marketing for Higher Education, 10(4), 1-11. http://dx.doi.org/10.1300/J050v10n04_01

Elliott, K. M., \& Shin, D. (2002). Student satisfaction: An alternative approach to assessing this important concept. Journal of Higher Education Policy and Management, 24(2), 197-209. http://dx.doi.org/10.1080/1360080022000013518

Frauman, E. (2005). Differences between participants and non-participants of campus recreation offerings across demographic variables and perceptions of the college experience. Recreational Sports Journal, 29(2), 156-165.

Gamage, D. T., Suwanabroma, J., Ueyama, T., Hada, S., \& Sekikawa, E. (2008). The impact of quality assurance measures on student services at the Japanese and Thai private universities. Quality Assurance in Education, 16(2), 181-198. http://dx.doi.org/10.1108/09684880810868457

Gibson, A. (2010). Measuring business student satisfaction: A review and summary of the major predictors. Journal of Higher Education Policy and Management, 32(3), 251-259. http://dx.doi.org/10.1080/13600801003743349

Günay, D., \& Günay, A. (2011). 1933’ten günümüze Türk yükseköğretiminde niceliksel gelişmeler (in Turkish). Yüksekögrretim ve Bilim Dergisi, 1(1), 1-22. http://dx.doi.org/10.5961/jhes.2011.001

Haines, D. J. (2010). The campus recreation assessment model. Recreational Sports Journal, 34(2), 130-137.

Hall, D. A. (2006). Participation in a campus recreation program and its effect on student retention. Recreational Sports Journal, 30(1), 40-45.

Henchy, A. (2013). The perceived benefits of participating in campus recreation programs and facilities: A comparison between undergraduate and graduate students. Recreational Sports Journal, 37(2), 97-105.

Hofstede, G., Hofstede, G. J., \& Minkov, M. (2010). Cultures and organizations: Software of the mind. New York: McGraw-Hill.

Hofstede, G., Neuijen, B., Ohayv, D. D., \& Sanders, G. (1990). Measuring organizational cultures: A qualitative and quantitative study across twenty cases. Administrative Sciences Quarterly, 35(2), 286-316. http://dx.doi.org/10.2307/2393392

Kallio, R. E. (1995). Factors influencing the college choice decisions of graduate students. Research in Higher Education, 36(1), 109-124. http://dx.doi.org/10.1007/BF02207769

Kuh, G. D. (2009). Understanding campus environments. In G. S. McClellan, J. Stringer \& Associates (Eds.), The Handbook of Student Affairs Administration (pp. 59-80). San Francisco, CA: John Wiley \& Sons, Inc.

Kwan, P. Y. K., \& Ng, P. W. K. (1999). Quality indicators in higher education-comparing Hong Kong and $\begin{array}{lllll}\text { China's students. Managerial Auditing Journal, } & \text { 14(1/2), }\end{array}$ http://dx.doi.org/10.1108/02686909910245964

Lacatus, M. L. (2013). Organizational culture in contemporary university. Procedia-Social and Behavioral Sciences, 76, 421-425. http://dx.doi.org/10.1016/j.sbspro.2013.04.139

Lai, A. P. C., Gibson, P., \& Muthaly, S. (2014). Becoming an education provider of choice in Hong Kong: An inquiry into student decision making. International Journal of Education Management, 28(5), 590-609. http://dx.doi.org/10.1108/IJEM-05-2013-0082

Lindsey, R. R. (2012). The benefits and satisfaction of participating in campus recreational sports facilities and programs among male and female African American students: A pilot study. Recreational Sports Journal, 36(1), 13-24.

Lindsey, R., \& Sessoms, E. (2006). Assessment of a campus recreation program on student recruitment, retention, and frequency of participation across certain demographic variables. Recreational Sports Journal, 30(1), 30-39.

Lindsey, R., Sessoms, E., \& Willis, G. (2009). Impact of campus recreational sports facilities and programs on 
recruitment and retention among African American students: A pilot study. Recreational Sports Journal, $33(1), 25-34$.

Long, J. S. (1997). Regression models for categorical and limited dependent variables. London: SAGE Publications.

Long, J. S., \& Freeze, J. (2001). Regression models for categorical dependent variables using Stata. Texas: Stata Press.

Mai, L. W. (2005). A comparative study between UK and US: The student satisfaction in higher education and its influential factors. Journal of Marketing Management, 21(7-8), 859-878. http://dx.doi.org/10.1362/026725705774538471

Martin, N. D. (2012). The privilege of ease: Social class and campus life at highly selective, private universities. Research in Higher Education, 53(4), 426-452. http://dx.doi.org/10.1007/s11162-011-9234-3

Melchor Cardona, M., \& Bravo, J. J. (2012). Service quality perceptions in higher education institutions: The case of a Colombian University. Estudios Gerenciales, 28(125), 23-29. http://dx.doi.org/10.1016/S0123-5923(12)70004-9

Miller, K. H., Noland, M., Rayens, M. K., \& Staten, R. (2008). Characteristics of users and nonusers of a campus recreation center. Recreational Sports Journal, 32(2), 87-96.

Milton, P. R., \& Patton, B. J. (2011). Who enters campus recreation facilities: A demographic analysis. International Journal of Sport Management, Recreation \& Tourism, 7(11), 11-29. http://dx.doi.org/10.5199/ijsmart-1791-874X-7b

Min, S., \& Khoon, C. C. (2014). Demographic factors in the evaluation of service quality in higher education: A structural equation model (SEM) approach. International Journal of Marketing Studies, 6(1), 90-102. http://dx.doi.org/10.5539/ijms.v6n1p90

Moosmayer, D. C., \& Siems, F. U. (2012). Values education and student satisfaction: German business students' perceptions of universities' value influences. Journal of Marketing for Higher Education, 22(2), $257-272$. doi: 10.1080/08841241.2012.746254

Moro-Egido, A. I., \& Panades, J. (2010). An analysis of student satisfaction: Full-time vs. part-time students. Social Indicators Research, 96(2), 363-378. http://dx.doi.org/10.1007/s11205-009-9482-1

Müderrisoğlu, H., Kutay, E. L., \& Eşen, S. Ö. (2005). Determining leisure time, recreational participation and requirements of university students in Düzce campus. International Journal of Urban Labour and Leisure, 7(1), 1-11. Retrieved from http://www.ijull.co.uk/vol7/1/muderrisoglu.pdf

Nunnally, J. C. (1978). Psychometric theory. New York: Mc-Graw-Hill.

Osman, R. W., Cole, S. T., \& Vessell, C. R. (2006). Examining the role of perceived service quality in predicting user satisfaction and behavioral intentions in a campus recreation setting. Recreational Sports Journal, $30(1), 20-29$.

OSYM. (2012). 2011-2012 academic year number of vocational training school \& undergraduate students. Retrieved from http:/www.osym.gov.tr/dosya/1-60426/h/5onlisanslisansduzeyogrencisay.pdf

Özer, H. (2004). Nitel değişkenli ekonometrik modeller: Teori ve bir uygulama (in Turkish). Ankara: Nobel Yayın Dağıtım.

Parahoo, S. K., Harvey, H. L., \& Tamim, R. M. (2013). Factors influencing student satisfaction in universities in the Gulf region: Does gender of students matter? Journal of Marketing for Higher Education, 23(2), 135-154. http://dx.doi.org/10.1080/08841241.2013.860940

Pettigrew, A. M. (1979). On studying organizational culture. Administrative Science Quarterly, 24(4), $570-581$. http://dx.doi.org/10.2307/2392363

Powers, D. A., \& Xie, Y. (2000). Statistical methods for categorical data Analysis. San Diego, California: Academic Press.

Price, I., Matzdorf, F., Smith, L., \& Agahi, H. (2003). The impact of facilities on student choice of university. Facilities, 21(10), 212-222. http://dx.doi.org/10.1108/02632770310493580

Sabbağ, Ç., \& Aksoy, E. (2011). Üniversite öğrencileri ve çalışanların boş zaman etkinlikleri: Adıyaman örneği (in Turkish). Mehmet Akif Ersoy Üniversitesi Sosyal Bilimler Enstitüsü Dergisi, 3(4), 10-23. Retrieved from https://edergi.mehmetakif.edu.tr/index.php/sobed/article/viewFile/302/220 
Sarrico, C. S., \& Rosa, M. J. (2014). Student satisfaction with Portuguese higher education institutions: the view of different types of students. Tertiary Education and Management, 20(2), 165-178. http://dx.doi.org/10.1080/13583883.2014.900108

Shanggui, S. (2013). The significance of university culture building for general education. In X. Jun, N. Pak-sheung, \& C. Chunyan (Eds.), General Education and the Development of Global Citizenship in Hong Kong, Taiwan and Mainland China (pp. 30-45). New York: Routledge.

Shank, M. D., \& Beasley, F. (1998). Gender effects on the university selection process. Journal of Marketing for Higher Education, 8(3), 63-71. http://dx.doi.org/10.1300/J050v08n03_05

Sirgy, M. J., Grzeskowiak, S., \& Rahtz, D. (2007). Quality of college life (QCL) of students: Developing and validating a measure of well-being. Social Indicators Research, 80(2), 343-360. http://dx.doi.org/10.1007/s11205-005-5921-9

Sivis-Cetinkaya, R. (2013). Turkish college students' subjective well-being in regard to psychological strengths and demographic variables: Implications for college counseling. International Journal for the Advancement of Counselling, 35(4), 317-330. http://dx.doi.org/10.1007/s10447-013-9185-9

Sojkin, B., Bartkowiak, P., \& Skuza, A. (2012). Determinants of higher education choices and student satisfaction: The case of Poland. Higher Education, 63(5), 565-581. http://dx.doi.org/10.1007/s10734-011-9459-2

Sökmen, A. (2011). Öğrenci memnuniyetine yönelik Ankara'daki bir meslek yüksekokulunda araştırma (in Turkish). İşletme Araştırmaları Dergisi, 3(4), 66-79. Retrieved from http://www.isarder.org/isardercom/2011vol3no4/e55.pdf

Tekin, M., Yıldız, M., Akyüz, M., \& Uğur, O. A. (2007). Karaman Yüksek Öğrenim Kredi ve Yurtlar Kurumunda kalan üniversite öğrencilerinin rekreatif etkinliklere katılım ve beklentilerinin incelenmesi (in Turkish)". Erzincan Eğitim Fakültesi Dergisi, 9(1), 121-135. Retrieved from eefdergi.erzincan.edu.tr/article/download/1006000702/1006001214

Terzioğlu, A., Yazıcı, M. (2003). Üniversite öğrencilerinin boş zamanlarını değerlendirme anlayış ve alışkanlıkları (in Turkish), Erzincan Eğitim Fakültesi Dergisi, 5(2), 1-31. Retrieved from http://eefdergi.erzincan.edu.tr/article/viewFile/1006000215/1006000125

Thomas, E. H., \& Galambos, N. (2004). What satisfies students? Mining student-opinion data with regression and decision tree analysis. Research in Higher Education, 45(3), 251-269. http://dx.doi.org/10.1023/B:RIHE.0000019589.79439.6e

Tylor, E. B. (1958). The origins of culture. New York: Harper \& Brothers Publishers.

Watson II, J. C., Ayers, S. F., Zizzi, S., \& Naoi, A. (2006). Student recreation centers: A comparison of users and non-users on psychological variables. Recreational Sports Journal, 30(1), 9-19.

Weese, W. J. (1997). The development of an instrument to measure effectiveness in campus recreation programs. Journal of Sports Management, 11(3), 263-274.

Wiers-Jenssen, J., Stensaker, B., \& Grøgaard, J. B. (2002). Student satisfaction: Towards an empirical deconstruction of the concept. Quality in Higher Education, 8(2), 183-195. http://dx.doi.org/10.1080/1353832022000004377

Wilkins, S., Balakrishnan, M. S., \& Huisman, J. (2012). Student satisfaction and student perceptions of quality at international branch campuses in the United Arab Emirates. Journal of Higher Education Policy and Management, 34(5), 543-556. http://dx.doi.org/10.1080/1360080X.2012.716003

Woosnam, K. M., Dixon, H. E. T., \& Brookover, R. S. (2006). Influence of campus recreation facilities on decision to attend a southeastern university: A pilot study. Recreational Sports Journal, 30(1), 70-76.

Yeo, R. K. (2008). Brewing service quality in higher education: Characteristics of ingredients that make up the recipe. Quality Assurance in Education, 16(3), 266-286. http://dx.doi.org/10.1108/09684880810886277

Young, S. J., Ross, C. M., \& Barcelona, R. J. (2003). Perceived constraints by college students to participation in campus recreational sports programs. Recreational Sports Journal, 27(2), 47-62.

Zhang, J., Zhao, S., Lester, D., \& Zhou, C. (2014). Life satisfaction and its correlates among college students in China: A test of social reference theory. Asian Journal of Psychiarty, 10, 17-20. http://dx.doi.org/10.1016/j.ajp.2013.06.014 
Zizzi, S., Ayers, S. F., Watson II, J. C., \& Keeler, L. A. (2004). Assessing the impact of new student campus recreation centers. Journal of Student Affairs Research and Practice, 41(4), 588-630. http://dx.doi.org/10.2202/1949-6605.1390

\section{Copyrights}

Copyright for this article is retained by the author(s), with first publication rights granted to the journal.

This is an open-access article distributed under the terms and conditions of the Creative Commons Attribution license (http://creativecommons.org/licenses/by/3.0/). 